\title{
Academic Odyssey: From the Mississippi to the Missouri
}

\author{
Arthur G. Umscheid
}

Arthur G. Umscheid was born and educated in Iowa. A student at The University of Iowa and later a teacher at St. Ambrose College, $\mathrm{Mr}$. Umscheid's early experiences and his subsequent ascendance up the academic ladder to Dean of the Graduate School at Creighton University in Omaha, speak of solid midwestern values, awareness of immigrant ancestry, knowledge of the history of his community, and commitment to personal and professional goals. Mr. Umscheid's reflections on his life offer insights from which present and future generations can draw universal lessons. - Ed.

Mark Twain entered this life under aegis of Halley's comet. My advent was less spectacular, coinciding with the autumnal equinox, September 21, 1909. The grandparents, weary of incessant strife and lack of opportunity, departed their native Bavaria and Rhineland, joined the mid-century tidal wave of immigration, made their way westward, settling on the banks of the Mississippi. Mother's parents spent their lives in Muscatine. The paternal grandfather, a stonemason, followed his trade only long enough to accumulate the capital to gratify the heart's desire of the German immigrant-some acres he could call his 
own. Settling first on a small farm at the foot of the Illinois bluffs, in 1882 he purchased more desirable land near Nichols, Iowa. The soil was fertile and productive, heavily wooded, with a delightful little creek, Wapsie, meandering through meadow and forest. Here four sons and three daughters were reared, sharing in the arduous toil before agricultural mechanization, imbibing the Germanic virtues of discipline, frugality and hard work. When years took their toll and children scattered, the parents retired to Muscatine. Theirs was a simple story, repeated on innumerable occasions, as pioneers pushed the frontier westward, cleared the forest, broke the tough sod, established homes, ultimately finding rest in the earth they cultivated and loved. The grandparents were gone before my time and something precious was lost. I envied playmates who eagerly anticipated Thanksgiving or Christmas at Grandma's, a joy I never knew.

Muscatine, with the unique charm of an old river town, provided an ideal setting for a happy boyhood. Slightly under 17,000 population, its atmosphere was relaxed and neighborly, marred only by an undercurrent of religious bigotry, surfacing in ugly manner during the revival of the Ku Klux Klan in the 1920s. Called the "Bend City," it stands where the Mississippi confuses one's sense of direction flowing from east to west, the sun rising and setting over the river. With an economy resting originally upon lumbering, it subsequently turned to manufacture of pearl buttons, excised from mussel shells abounding in the river, becoming known as the "Pearl City." But inevitable change transformed all this as the lustrous and iridescent pearl yielded to more practical plastic and zippers, undermining the industry, now a shell of former greatness and largely a memory of bygone days.

Dominating the life of the community was the majestic "Father of Waters." Hours can be spent in Riverview Park contemplating the mighty stream as it passes the city in eternal quest of the ocean. Imagination paints the vision of pristine beauty as seen by the eyes of Father Marquette, Joliet and LaSalle, when it came unspoiled from the hands of God before it knew the pollution that comes from the hands of men. There is no more wondrous memory of boyhood than recalling a 
cruise at sunset in a small craft resting only inches above the surface. At that hour the stream is usually placid, reflecting in its waters the glory and magnificence of the heavens, an illusion of beauty and majesty, one the most renowned artist could not recapture. Richly do those sunsets deserve the oft-quoted accolade of Mark Twain in his Life on the Mississippi. To pass the days of childhood along the banks of the great stream is to fall everlastingly under its spell. The river, like the mountains, is a creature of changing moods. Ice-locked and forbidding in the vise of winter, menacing in springtime floods, sullen and dark with angry whitecaps under a threatening sky, blue and serene under the smile of a summer sun, but transfigured in glory as it mirrors the celestial splendor of the western sky at sunset.

Spanning the river, linking Muscatine with the Illinois shore, stood the High Bridge. Like Liberty, overlooking New York harbor, and the Gateway Arch of St. Louis, for three generations it was the symbol of the city, fascinating to behold as its delicate web first appeared to passengers on a steamer rounding the bend. Opened May 8, 1891, it carried its years gracefully, stone piers anchored deeply in the river bed, its central span allowing passage of steamboats, belching black smoke from twin stacks, as they glided beneath its vaulting arch. It is gone now, its demolition completed April 5, 1973. Erected to transport horse and buggy traffic of the 1890s, no doubt its time had come, but a sense of nostalgia remains. The new bridge, a short distance above the old, was opened December 8, 1972; a single stone pier was retained, a monument to what had been before. Today the ornate white riverboats with their whistles, sometimes piercing, sometimes thunderous, with their decorative carvings and frills, no longer raise the silvery spray from paddlewheels. They have been replaced by fleets of barges hauling freight from the Twin Cities to New Orleans, with Muscatine as a major terminal. The "Pearl City" of yesterday has become the "Port City" of today.

The transcendent influence on my life was my father. Reared on a farm, product of a one-room schoolhouse of the $1880 \mathrm{~s}$, he was the personification of the self-educated man. He entered partnership in a book store, read books, loved books, instilling that affection in me. Genteel, soft-spoken, liberal, tolerant, 
compassionate, those who knew him loved him. To a son he was an ever-present source of sympathy, understanding, guidance, a solace in times of disappointment, these traits blended with insistence upon discipline, never onerous but always firm. An amateur naturalist of some reputation, he loved the manifestations of nature-trees, wild flowers, clouds - with a preeminent attachment for ornithology, as there was not a bird in the Mississippi valley whose song, number and color of eggs, nesting habits and migratory patterns he did not know. When the final summons came, the attending physician, the mortician, the officiating clergyman-all men who knew death as daily routine-in a tribute rarely accorded, gave vent to tears.

Mother was cast in a different mold, less tolerant of a small boy's antics, less outgoing in personality, less able to attract friends. In most respects the typical Hausfrau, her interests were confined to the home, church and a small circle of ladies with whom she enjoyed a biweekly round of cards. There were some who, perhaps, did not make allowance for changes in personality that came with a prolonged period of declining health but they never shared the memories of sitting on her knee to learn their prayers or listen to her read Moore's "A Visit from St. Nicholas." The old home lacked a fireplace but Santa always managed entry and stacked the mysterious packages beneath the tinseled tree she decorated with loving hands. Like father, she sacrificed much that it might be given to me.

Father often admonished that childhood is brief, meant to be a happy time, the prelude to long years of work and responsibility. It passed all too soon in boyish pursuits-chasing the ice wagon to retrieve shavings, playing sandlot baseball and fretting about payment for the neighbor's broken windows, dawn to dusk on the tennis courts, and innumerable visits to my uncle's farm near Nichols, an exciting world to a town-bred boy. Father insisted that one should know the meaning of work, so annually, in days before combines, we went into the harvest field, gathered the sheaves as they were spewed forth from the reaper and binder, stood them in shocks, awaiting the threshing crew. In the broiling heat of July, with no vestige of shade, one 
The Annals of Iowa

quickly grasped the implications of Genesis: "In the sweat of thy brow ..."

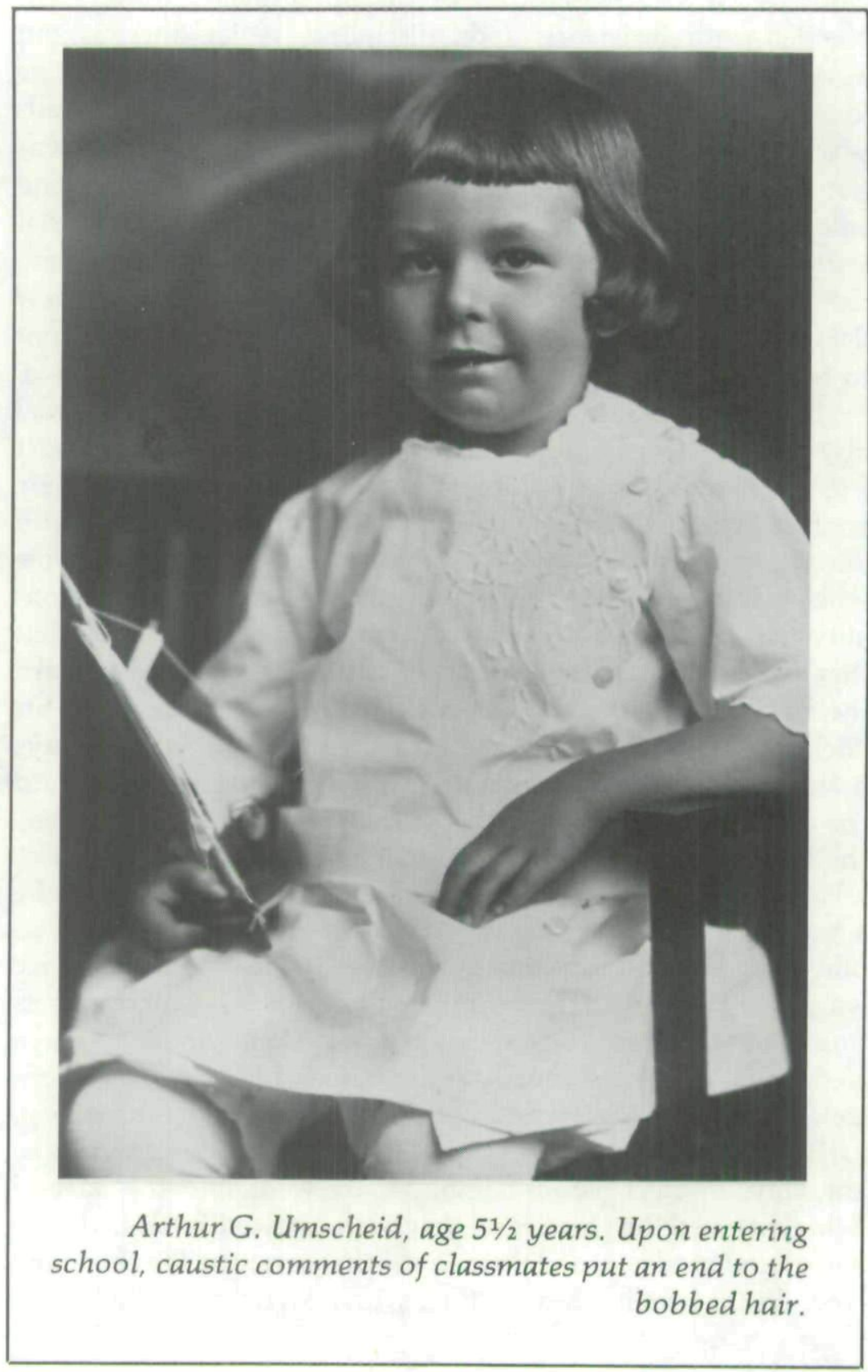


The three Rs were learned in a small parochial school, a red brick building erected in the 1880 s, standing in the shadow of an imposing church of Romanesque design with domed tower, surmounted by a golden cross, enclosing the clock and bells sounding the quarter-hours. One could scarcely conceive of Muscatine without the chimes of St. Mathias. High school years followed in the same building, all classes taught by three nuns, responsible for some ninety students. There was no stadium, no fieldhouse, running track or swimming pool, but despite lack of these costly embellishments of modern secondary education, all graduates could read, write and calculate.

The school was so small there was little of extracurricular nature. Mother insisted upon piano lessons, given by a sweet little nun, a saintly character at whose death the angels must have vied for the privilege of conducting so beautiful a soul to the feet of the Master served so faithfully. Half an hour daily practice was expected and performed under duress, one eye on the clock, the other upon the more fortunate chaps playing ball outside. It soon became apparent that I was no Rubinstein or Horowitz, but a love and appreciation of good music remained, enriching life to this day. Graduation came in June, 1927, closing, as it always does, a chapter in one's life.

Father promised me the opportunity of college and it was inconceivable that he would not honor his pledge. It was, therefore, a shock, when, in a manner totally unlike him, he informed me that I would not be entering college in the fall but would be required to work for one year. It must have been our only conversation in which it was made clear at the outset that the point was to be accepted, not discussed. Loving books as he did, it was startling to hear him say there were three things in life, vital to one's education, that could not be learned from books: 1) how to meet people and get along with them; 2) how to smile when you wanted to throw a brick; 3) the value of a dollar. Subsequent years proved him correct, but it was a shattering experience at the moment. Making the fatal blunder of being honest, I told prospective employers that work was desired for one year and failed to understand why they immediately lost interest. 
Every boy, finishing high school at age seventeen, expects to launch his career as vice president of the corporation. It was a blow to my dignity when, several weeks later, employment came, clerking in an outskirts grocery store. My boss could outrun the truant officer and dropped out of school about sixth grade, but what he lacked in formal training was offset by an abundance of common sense. Hours were long, 7:00 A.M. to 6:30 P.M. during the week, 11:00 P.M. on Saturday, the work easy at times, arduous at others, especially when duty involved wrestling bushels of potatoes and hundred-pound bags of sugar. By modern standards the compensation was scarcely munificent at $\$ 8.00$ weekly. The experience may not have equalled a degree in Business Administration, but one learned much about merchandising and, more important, human nature, which manifests itself in strange patterns in the purchase of foodstuffs.

The year, threatening to be eternal, passed with surprising swiftness. Though I have long been away, memories of Muscatine remain fresh, leaves in a treasured album. Like neighboring river towns, it has a fascinating history but regrettably the community has, until very recently, shown little attachment to a heritage so rich. It has permitted too many landmarks to be destroyed, as if apologetic for its past. There is still a sense of mingled pain and remorse in recalling the destruction of Mark Twain's home, that stood near the river bank, beside the High Bridge as one entered the city. It was leveled to make space for a filling station. Whether the few paltry dollars infused into the municipal economy compensated for the loss of an historic shrine is a matter of conjecture, best left to banker or accountant. It would seem that so little was gained and so much irretrievably lost. ${ }^{1}$

There is a deep sense of nostalgia in returning now. Once a city of trees, thousands of noble elms have been lost to disease. Family friends and associates are mostly gone. So many familiar scenes have changed and one quickly detects breathing a different atmosphere. The High Bridge is gone; the railroad station is gone and wide-eyed youngsters no longer stand beside the tracks to watch the passage of the Golden State Limited. The old public high school on Iowa Avenue, crowded with a myriad of memories, is gone. Urban renewal has renovated the 
downtown; shopping centers and suburban dwellings have taken over the outskirts, encroaching upon the wooded areas where I roamed as a boy. But one immutable link remains, binding days that are gone with those yet to come-" Old Man River, he just keeps rolling along."

In September, 1928, freshman registrants at St. Ambrose College included a lad torn by mixed emotions-grateful for the opportunity, yet disturbed at breaking close home ties. Founded in 1882, with intent of preparing students for seminary, the college was small, enrolling 189 men, mostly freshmen and sophomores. There were but three buildings, Ambrose Hall, a rambling red brick Victorian structure, partially encompassed by a grove of magnificent oaks, the gymnasium, and Davis Hall, a recently completed dormitory. A new science hall, Lewis, would soon be under construction.

Situated on heights characteristic of river towns, one faculty member, unable to set aside Harvard antecedents, remarked that the institution ". . . was built upon a bluff and run upon the same plan." This was quite unfair, as the faculty possessed men of high competence; Takkenberg in English, $\mathrm{O}^{\prime}$ Connor in philosophy, Kinnavey in Latin, Meinberg in history and Hauber in biology were teachers of superb quality who could easily have filled university chairs had they not elected to assume the Roman collar.

The faculty, predominantly clerical, took seriously the role of acting in loco parentis. Discipline was strict; one night out weekly; one weekend at home monthly, only if grades were satisfactory; confinement to the campus for trivial offenses. Dormitory lights were extinguished at 10:00 P.M. and it was mildly disconcerting to have the dean, who delighted in his alternate title, "Master of Discipline," prowling the corridors any hour of the night, jamming his master key into the lock, shining his flashlight into one's face for assurance a student was not A.W.O.L. The same dean offered an alleged course in psychology and kept the students quite docile by his presumed 
skill at mind-reading and his prescience of intended infractions of rules.

With no vocation in mind, it was during sophomore year a decision was slowly reached to enter historical studies. As such a program was unavailable at St. Ambrose, I applied for admission to The University of Iowa, entering as a junior in the fall of 1930. Transferring from a small denominational college to the open secular atmosphere of a university, enrolling almost 4,500 students, was somewhat traumatic.

The Department of History offered courses in broad areas of European, British and American history. Russian, Far Eastern, Latin American, and African Studies lay well into the future.

Chairman was Dr. Winfred T. Root, American colonial specialist, who had studied under Woodrow Wilson at Princeton and who possessed features bearing a remarkable resemblance to Wilson. Root, a bit devious at times, inclined to favorites, not a shrewd judge of men, presided over a department torn by considerable dissension, but unguarded moments revealed a man of warmth and congeniality.

First to take interest in me was Clara Daley. With silvery hair piled atop her head, sparkling dark eyes, vivacious and energetic, she invited me to her office, inquired my intentions and urged me to begin immediately the study of foreign languages. The advice was sound as I realized later on observing overburdened graduate students struggling with basic French and German grammar.

Harrison John Thornton was a brilliant lecturer, eloquent in language, precise in diction, with rare ability to breathe life into the past. In his "History of the South" one could inhale the atmosphere of the plantation, watch the harvesting of cotton and smell the Virginia hams in the smokehouse.

Two years were spent as teaching assistant to George Gordon Andrews, a French Revolutionary and Napoleonic scholar. He was not a gregarious personality, seldom remained in his office, yet had a sympathetic attitude toward student life and problems. His premature death closed a promising career.

Louis Pelzer, an able man, stickler for sources and method, was the only member of the department under whom I had no work, as the American West was remote from my program. He 
offered the seminar in Methodology, much to my later embarrassment, as my doctoral dissertation contained the audacious statement that the great works of historiography are not found in a pyramid of footnotes. Pelzer had some reservations on that point.

A vital, vibrant, vigorous personality, overflowing with ebullience and enthusiasm, was W. Ross Livingston. Gifted with a feel for history as living experience, he could never dwell upon Lee's surrender to Grant at Appomattox without tears running down the cheeks. Possessed of a stentorian voice and booming delivery, his words reverberated through the classroom and beyond and, when windows were open, it was said that everyone on the Iowa campus took Livingston's course, whether registered or not. No one could long be exposed to his influence without becoming infected with his passion for "Responsible Government."

Most lovable, the incarnation of Cardinal Newman's classic definition of a gentleman, was Harry Grant Plum. Slight in build, soft-spoken, unassuming, he had incredible faith in human nature, leaving his office door always unlocked, inviting students to browse the well-stocked shelves, take any book, merely leaving one's name on a spindle atop his desk. Since few people feel compulsion to return a book, losses must have been substantial.

The master-student relationship is most intimate between a graduate student and the one who directs his research and program. This was Dr. Cornelis Willem deKiewiet, a man of high scholarly attainments, sharp and incisive mind, demanding perfection, fluent in languages, holding the doctorate from London with subsequent study in France and Germany. Working under his guidance involved fluctuating between heights and depths, gratitude for the privilege of association with a person of his talents mingled with moments of despair when contrasting his brilliance with my limitations. Stories about him are legion, but from personal experience one remains uppermost in my memory. My father had lost half his life's savings in the Depression and now in retirement was too old to recoup. With my future in the university much in doubt, deKiewiet offered funds from his personal resources to insure continuation of my 
studies. Fortunately, his generosity proved unneeded, but it will never be forgotten. He left Iowa in 1940 to pursue a distinguished career at Cornell, later becoming president of the University of Rochester, a post he held until retirement. The debt to him could never be repaid and over all these years he remains my beau ideal of a "university man."

Confining one's program to a single department means limited contact outside its circle, but inevitably student life leads to other doors. No one was ever quite the same after an interview with Carl E. Seashore, redoubtable dean of the Graduate College. Tall and imposing in appearance, pink complexion, sparse silver hair and eyes that peered over halfmoon glasses, he had, unknown to me, a fetish for physical fitness. Knowing my future depended upon a scholarship, I approached his office with trepidation, but quite unprepared for his greeting, a gruff command: "Put out your hand." He examined it with the expertise of a palmist, while inwardly I shuddered, wondering what this had to do with a scholarship. Finally, he relaxed his grip and said: "If you had put out a soft, flabby hand, there would be no scholarship." His pamphlet, "The Wages of a Scholar," was required reading, along with attendance at his annual lecture to the graduate student body, never revised, as he sharply rapped the lectern, ordering us ". . . to plunge in medias res."

Taking the wise advice of Clara Daley, I registered for German, thus meeting Charles Bundy Wilson, departmental chairman. A kindly man with quizzical blue eyes, ruddy face, hawklike nose and hair of spun silver, he had a penchant for co-eds and found much satisfaction, after four or five boys missed a question, in saying: "Now, Fräulein Schmidt, you tell the boys the answer." Lamenting one day the fate of Latin study he ventured the observation that not a single member of the class could quote a line of Vergil. Calling his bluff, I recited the opening lines of the Aeneid. Fortune smiled that day; after that I could do no wrong! Months later I visited his office to inquire the date for the Ph.D. reading examination. He said nothing, reached leisurely into his desk, took out a card, signed it, handing it to me with the statement: "File this at the Graduate Office; you have just passed your examination in German." 
Every campus has its "characters"-Iowa was no exception. Conspicuous was Benjamin Franklin Shambaugh, chairman of Political Science. Tall, handsome, sartorially elegant in tweeds, brown shoes, $\tan$ fedora, scarlet tie, he strode the walks, swinging his cane, dubbed by the Des Moines Register as the "Lord Chesterfield of the campus." He loved the role of marshal at commencements, which involved calling out the names of those receiving Ph.D. degrees. Having an unusual name that was often mispronounced, and not wanting my great day marred, I took my chances by calling at his office and coaching him on correct pronunciation.

President of the University (1916-1934) was Dr. Walter Albert Jessup. I had no personal contacts with him-he moved in ethereal realms far from those of a mere student. Today he would be an anomaly, for he was an educator, not a public relations man or fund-raiser. Dr. Jessup was a worthy successor to that line of educational statesmen who guided leading American universities to greatness before and after the turn of the century. Retiring from Iowa, he became president of the Carnegie Foundation for the Advancement of Teaching.

The author during his senior year at college, in 1932.

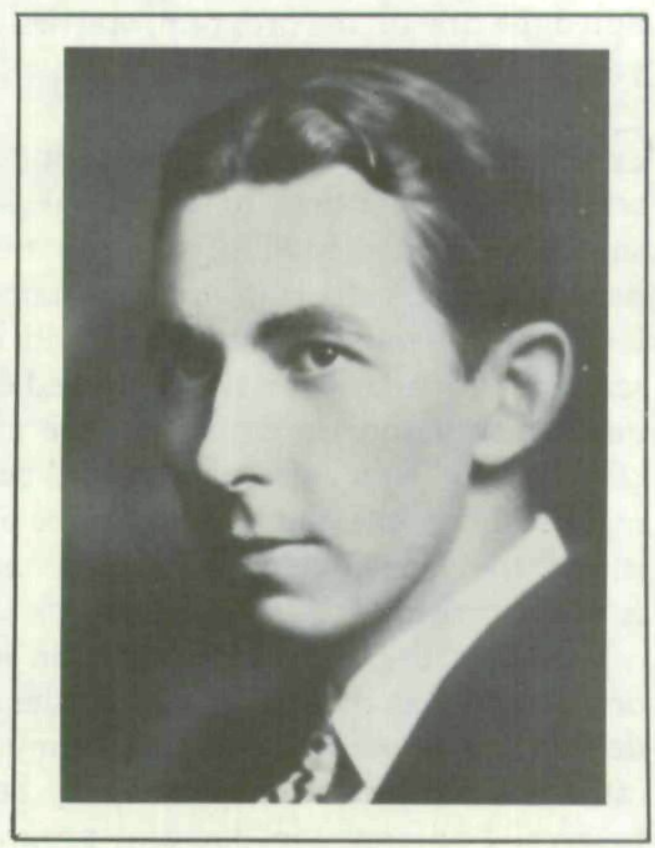


Junior and senior years passed rapidly, though the pall of the Great Depression hung over every aspect of student life. The blackest hour struck when news circulated the streets that all Iowa City banks had closed their doors. This produced the appalling thought of what to do about such matters as room and board, a crisis temporarily alleviated when the genial proprietor of the Princess Cafe informed my roommate and me that we could "eat now and pay later." How, was another matter! Commencement, 1932, brought the Bachelor of Arts with its invitation to challenge a world totally indifferent to the fate of another history major.

As my hands were neither soft nor lily-white, I survived the confrontation with Seashore, receiving a scholarship providing two-thirds remission of tuition (then $\$ 48.00$ a semester) and a stipend of $\$ 200$ in ten monthly payments. In the subsequent doctoral years, with no funds available, graduate students on fellowships were assigned rooms in the Quadrangle in lieu of stipend. In tune with the times, deKiewiet gave me, as master's thesis topic, a study of the English depression, 1873-1886. In his remarks at the graduates' dinner, President Jessup, having noted the title on the program, startled me by saying: "Thirteen years-that's a lot of depression."

Graduate study brought introduction to the techniques of research with countless hours in the stacks handling original source materials, mulling through nineteenth century newspapers, periodicals, Hansard's parliamentary debates, and the inexhaustible mine of data in the British "Blue Books." Though searching for articles on the depressed economy, there were frequent distractions, especially in the many essays on Britain's cemeteries, which aroused a morbid curiosity. Considering the millions of people and their centuries of residence upon a small island, they were evidently running out of burial space-which is not surprising!

The M.A. degree was conferred in July, 1933. This was the original goal as the Ph.D. seemed the impossible dream. With deKiewiet's reassurance to bolster my lack of confidence, my father's commitment to loan money he could no longer afford to give, I entered the doctoral program in the fall of 1933, 
having passed the qualifying examinations in conjunction with master's finals.

Owing to the nature of the times, I taxed myself rather severely to complete the program in minimum time, imprudent but necessary. August, 1935 came and with it the final orals, held by tradition in Old Capitol. With deKiewiet on leave, I had no advocatus diaboli, and Root presided. It went quite smoothly, though Pelzer seized the opportunity to slip in some barbs on methodology and footnotes. The ordeal concluded with customary congratulations to the newly created Doctor of Philosophy. When the signatures on the diploma were still wet, I was modest enough not to think I knew all the answers, only most of them. Forty-five years later I am much less certain. August 22, 1935, in a hot and stuffy Memorial Union, Dean Seashore draped the hood about my shoulders; Shambaugh correctly pronounced Umscheid. Like all commencements, it was both an ending and a beginning.

In this time of Depression, the fact there was neither a job nor a remote prospect of one was most depressing. With educational institutions under tight budgets, opportunities were severely limited. Applications were made and returned, always with assurance that credentials were impressive, but always some technicality precluding a contract, possibly my religious convictions, but since such discrimination is invariably insidious, this could never be established.

The final days of August were passed resting at my parents' home, wondering about an unpromising future and the apparent futility of the long struggle. It soothed the ego to be addressed as "Doctor," but to what purpose? Then came a telephone call from the president of St. Ambrose. On learning I had no job, he requested that no contract be signed until hearing from him again - a request more superfluous than he knew! A day or two later he called, offering an appointment at my old school, $\$ 1,400$ a year, plus dormitory room, and board at the faculty table. Needing the experience, anxious to repay indebtedness to my parents, I was in no mood to dicker and probably startled the good Monsignor with the alacrity of acceptance. Little had changed on the familiar campus since I was a student there-private schools in the 1930s were con- 
cerned with survival, not expansion. But everything seemed different as a member of the faculty, poised on the threshold of an academic career. The transformation from student to professor now began.

The schedule at St. Ambrose assigned classes in Modern Europe, American History and Government. The enthusiasm of a novice made each class exciting as passing days quickly erased the "butterflies in the tummy" complex of a neophyte instructor. There was challenge in handling young men, attempting to stimulate thought and independent judgment, to broaden horizons, hopefully even to inspire. Little time existed for outside activities, none for research, as a beginning instructor is hard pressed, without a previous year's notes, to keep the traditional "one day ahead of the class." The Bohemian attire of a graduate student, reflecting Groucho Marx's observation on the "threadbare "thirties," was inappropriate for the classroom, so the first of the month was eagerly awaited to replenish a depleted wardrobe, to repay the loan from my parents and to face the world free of obligations.

Board at the faculty table presented problems but few alternatives. The business manager, a shrewd character, faced with the formidable task of keeping the institution solvent, missed no opportunity for cutting corners and costs. He evidently sensed a rare bargain in purchasing a carload of canned green beans, possibly the residue of a derailment, so they became a twice daily feature of the menu; it was some years before I could contemplate the thought of this delectable vegetable without rumblings of inner protest. The aversion was too well known on campus. On the eve of Christmas vacation students were allowed to stage a skit panning the faculty; Santa presented me with a can of beans!

Spring, 1936, brought an invitation to join the summer faculty of Creighton University. It was an unforgettable experience, a summer of unprecedented heat and drought, setting an all-time record of $114^{\circ}$ in July, no air conditioning, classes 
every morning, preparations every afternoon, contending with the lassitude accompanying unremitting heat. Following an August trip to Canada and the Eastern seaboard, September brought return to St. Ambrose for the academic year.

Later in the year a difficult decision presented itself. A letter arrived containing an invitation to assume a permanent position on the Creighton faculty. There was a nostalgic attachment to St. Ambrose, memories of student days, tempered by a sense of gratitude for the offer of a position when the world seemed very bleak. But there were also realities, for in a small diocesan college the ax hung ever suspended above the head of a lay instructor, who would be replaced as soon as a cleric acquired necessary credentials.

St. Ambrose was administered and staffed by secular clergy, Creighton by the Society of Jesus. The world of the Jesuit Order was largely foreign to me. Their proud tradition in European educational circles was well known, and equally so their controversial character-detractors condemning them as unprincipled, conspiratorial, using any means, legitimate or illegitimate, to attain a desired goal, their apologists praising accomplishments of a dedicated, disciplined body of men from whose ranks came saints, educators, scholars, scientists and missionaries. Even Parkman, striving for historical objectivity, encountered a dilemma, unable to conceal his distaste for them, equally unable to restrain his admiration for the courage and heroism of the North American martyrs.

September, 1937, was not the most propitious moment to enter the faculty of Creighton. Like all private institutions it had fought the battle for survival during the Depression; unlike many others, it succeeded. The campus lay on the fringe of Omaha's business district, mostly old buildings with a rundown appearance, set too closely together for want of space, interspersed with residential dwellings. But a young instructor, brimming with zeal and enthusiasm, was largely oblivious to all this.

A background too cosmopolitan may bring problems. Having majored in European, minored in American, with dissertation in British history, the department soon congratulated itself in acquiring a "Renaissance man," possibly the first universal 


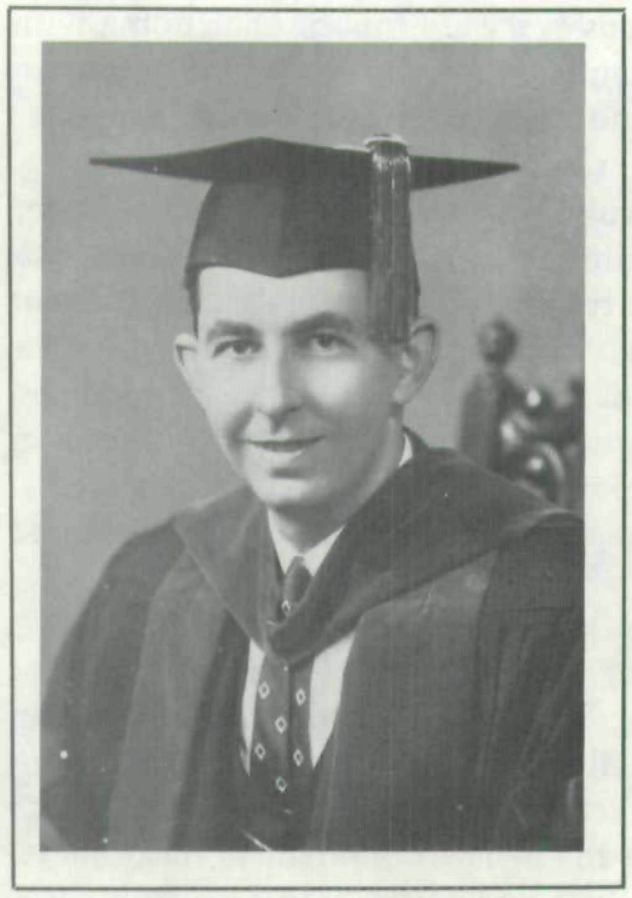

A studio portrait taken in the spring of 1938 as an instructor in history at Creighton

University.

genius since Aristotle, who could teach anything! The teaching load was demanding, full-time in every academic year, plus twenty-six consecutive summer sessions, save for a sabbatical in 1958. On October 7, 1937, I married a radiant and lovely young woman, who for forty-two years has shared the assets and liabilities of academic life, never once suggesting that had I entered medicine, dentistry, or law, I might have amounted to something. A daughter was born in 1938, a son in 1939, bringing happiness along with the responsibility of balancing family budgets in times of very low salaries, a situation requiring eleven of every twelve months in the classroom.

There was no time for research and the university did nothing to encourage it. Sabbaticals before 1958 were unknown, grants and fellowships virtually non-existent, foundation support uncommon, and massive federal funding awaited Sputnik in 1957. The university, struggling for solvency, could not fund such endeavor; a dean would have spurned requests for reduced schedules or leaves and questioned the sanity of one who asked 
money for research support. There was, consequently, little or no opportunity for scholarly productivity, a matter of regret but no apology. The College of Arts and Sciences showed wide discrepancy between numbers of entering freshmen and graduating seniors, serving too often as a "feeder" for the professional schools and less the independent unit that should constitute the foundation of university structure. Large lower division classes taxed one's strength, but upper divisions were small and majors few. Emphasis was placed upon effective teaching and herein lay the excellence of the college. It possessed an unusually high percentage of thoroughly competent men, whose dedication and loyalty contributed greatly to its survival during the troubled 'thirties.

Creighton is one of twenty-eight Jesuit colleges and universities in the United States. With high schools added, the American Jesuits, in an outburst of apostolic zeal, overextended themselves in assuming a burden so formidable. The university's foundation dated from a bequest of $\$ 100,000$ in the will of Mary Lucretia, widow of Edward Creighton, a distinguished Omaha pioneer, the grant fulfilling a dream of her husband who died prematurely and intestate at fifty-four. Beginning in 1878, with 200 students at elementary level, it struggled for existence, survived the Depression of the 1890s, developed slowly, gradually emerging to university status with Medicine (1892), Law (1904), Dentistry (1905), Pharmacy (1905), Business Administration (1920) and the capstone, the Graduate School (1926).

Unlike today, the university was governed in authoritarian fashion in tune with the military traditions of the Order. Overburdened presidents, with tenures all too brief, also served as Rectors of the Jesuit Community, made all major decisions and far too many minor. The curriculum reflected European backgrounds, a strong Classical influence, with every candidate for the baccalaureate degree meeting requirements in philosophy and theology, at that time a hallmark of Jesuit education. Lay faculty, outside the professional schools, were not involved in governance, a trifle stultifying to a young instructor, brimming with ideas on how a university should be administered. 
The Annals of Iowa

Associate Professor Umscheid in 1945

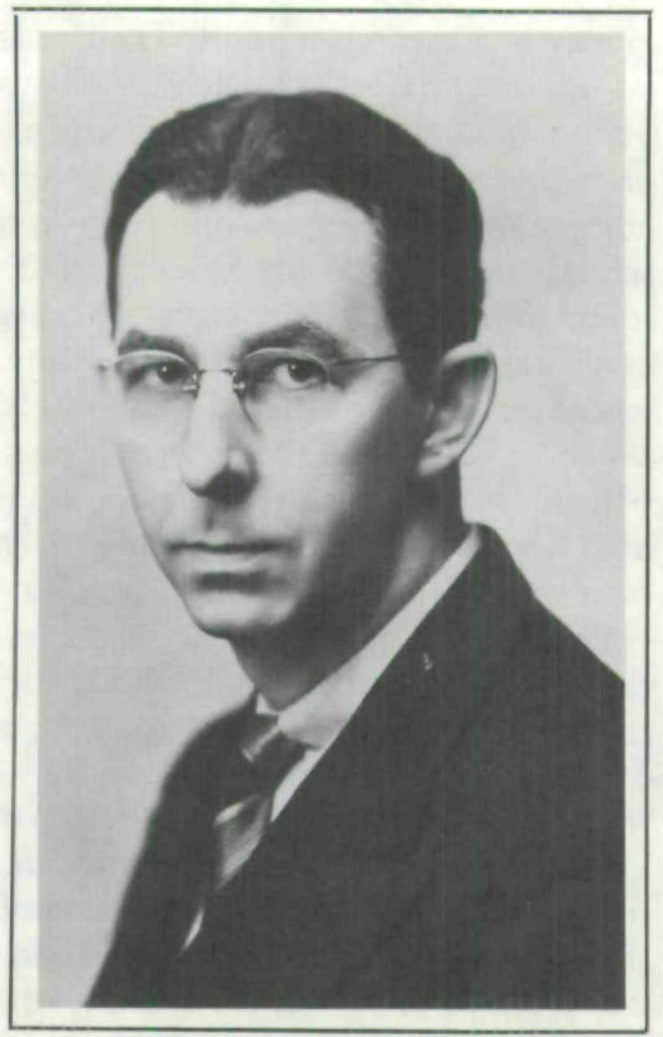

Students here were much like students elsewhere. Stricter admission standards insured higher quality, bringing a sense of satisfaction in working with them, observing their growth and unfolding, assisting toward projected careers, opening doors to advancement, chatting with them in the office, sharing their confidences, encouraging their dreams, commiserating with frustrations and disappointments. Doubtless, all this has changed little since the medieval universities.

In late May, 1957, the departmental chairman fell victim to a massive stroke. Several weeks later the succession descended upon me, the first taste of administration. The department had functioned smoothly with no reason for drastic change, but it was disconcerting to find history majors, who knew textbooks and outlines, but were unacquainted with the writings of such masters as Gibbon, Macaulay, von Ranke, Parkman and 
Prescott, to mention but a few. To remedy this a required course in readings was instituted. A chairmanship often leads to discovering that colleagues, hitherto affable and congenial, suddenly assume personalities quite foreign when given assignments contrary to their inclination. There are times when professors could teach temperamental operatic prima donnas a trick or two!

One day in spring, 1963, my telephone rang. It brought an immediate summons to the president's office without the slightest intimation of purpose. The outcome of the interview, leaving me somewhat stunned, was an offer to assume the deanship of the Graduate School. After several days of consideration and consultation with my wife, acceptance was given, accompanied by my firm resolution that the multitude of problems would remain upon the office desk, never taken home, a vital prescription if one hopes to avoid ulcers.

There was no period of apprenticeship, the operation was totally strange, but one must learn quickly when survival is at stake. The graduate deanship is unique in the manner in which it evolved in the structuring of the American university. Presumably an administrator is selected in terms of personality, background and competence for the position, given the authority to handle it and held strictly accountable for exercise of that authority. But in the Graduate Office the game is not played under those rules! There are weighty responsibilities but no commensurate authority. Here, as elsewhere, money talks, but faculty are on the payrolls of their respective colleges; the dean, with only an operating budget for his office, has no financial leverage. A professor will give sober, second thought before thumbing his nose at the Arts dean, who controls his salary, but for the graduate dean it is always "open season." There is virtually no power to order anything done-only responsibility and blame when it is left undone. If a chairman goes his merry way without consulting the Graduate Office, and a subsequent mess results, it ends up on the dean's desk. The position really demands a fortuitous blending of magician and diplomat-the magician who accomplishes the impossible by waving his wand, the diplomat who must win his objective by persuasion, tact, entreaty, cajolery and pleading. Each department is jealous of its prerogatives and protecting its miniature empire 
and the dean must artfully dodge the crossfire between the academic vice president and the chairmen, between feuding professors, between professors and students. So he probes his way through the maze, seeking to pour oil on troubled waters, balm on injured egos, soothing ruffled feelings, trying to get something accomplished, ever mindful of the futility of threat or command.

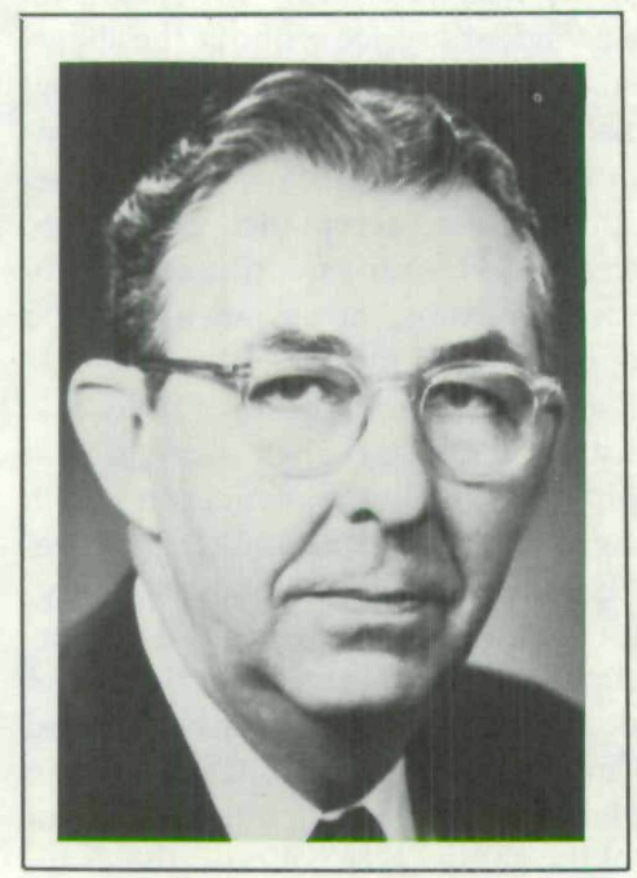

Dr. Umscheid served as Dean of the Graduate School, Creighton University, from 1963-1973.

The Graduate School was a relatively small operation, conferring advanced degrees only at master's level. Without a doctoral program it was ineligible to share in the bountiful largess poured forth by the federal government in the postSputnik era that led to unprecedented expansion in graduate education. Old programs were modified and new ones instituted in tune with changing times but the greatest satisfaction came in 1969 when, after a long, difficult and involved procedure, the university received accreditation to confer the Doctor of Philosophy degree, thereby attaining the fullness of university status. The successful accomplishment of this objective was its own reward. The supreme moment of an academic 
career came in standing upon the commencement platform, calling the names, presenting the first candidates, and watching the doctoral hood, lined with Creighton's blue and white, placed upon their shoulders.

University policy stipulates, in ordinary circumstances, a term of ten years for a dean. This permitted honorable resignation in 1973 and return to the classroom for the one year remaining before mandatory retirement. Ultimately it arrived and with it some strange sensations. Over forty years of classroom lecturing, supervising graduate students, service on innumerable committees, a stint as radio news commentator, intensive public speaking, memberships and offices in various civic organizations, someone always waiting in the dean's anteroom, multiple telephone lines jangling, attendance at regional and national deans' meetings - and suddenly, one morning a man awakens in a new and strange world, struggles to comprehend what has transpired, and, like the pugilist on the canvas, shakes his head vigorously to clear the cobwebs before the count of ten.

If retirement brings occasional restlessness and questioning, it brings compensating blessings as well. Relief from strain and pressure, the opportunity to move leisurely while ignoring the tyrannical clock, the chance to read those things one wishes to read rather than those imposed by duty. There comes a delightful sense of mañana that whatever comes can always wait for tomorrow. Strangely enough, merely being ignored and left to one's own devices creates a mood of indefinable satisfaction. One can still find fulfillment in possession of a quiet office, teaching one course each semester, remaining in association with young people, continuing to be useful, and not merely dreaming of what once was and can never be again.

\section{IV}

$I_{t}$ is relaxing to gaze through the east window of the office, to permit one's eyes to wander across the river and focus upon the rugged bluffs of my native state, observing how they record the passage of the seasons-the pristine freshness of early spring, the deeper green of summer, the flaming hues of autumn, the 
soft, white blanket of winter. Such a vista often induces a mood of contemplation, leading one to ponder upon forty-five years in higher education in Iowa and Nebraska and to meditate upon some of the implications of this pilgrimage.

This academic odyssey from the banks of the mighty Mississippi to those of the muddy Missouri has been short in distance but long in time. At oral examinations for advanced degrees some member of the committee is almost certain to ask the candidate: "If you were to do this over again, what would you do differently?" Students should be told not to fear making mistakes, for we learn by making them. But they should also be admonished by the old adage that a wise man never makes the same one twice. This may disqualify me from entering the Temple of Wisdom for if this half-century spent treading the groves of academe was a mistake, I would doubtless repeat it.

Contrary to popular impressions, it has not been an "ivory tower" existence. If one gives the utmost to one's calling, there will be little time to dwell in the tower, ignoring the "real world" outside. It is no royal road to riches, if this be the objective of life, but there are rewards that do not lend themselves to the balance sheet. There is an indefinable sense of satisfaction in the stimulus of intellectual pursuits and daily association with colleagues, men and women of cultivated tastes. There is a rare feeling of accomplishment, known only to the teacher, as he observes the development of a student and marvels at the mysterious metamorphosis of the unsophisticated freshman into the mature and polished senior. There is genuine thrill in working, not with charts and blueprints, not with bricks and mortar, not with concrete and steel, but with emergent human minds and personalities and finding at least a transitory immortality in impressing one's own characteristics upon them. Few must there be who do not find in later life that they owe much of what they are to the influence of some particular teacher.

Learning is an individual process-no one can learn from us. The role of the teacher is to guide, supervise, direct and stimulate. Woodrow Wilson, a distinguished educator before entering politics, once remarked: "You cannot educate a man; he must educate himself, and the way he must do this is by read- 
ing. The most we can do is to direct that reading." Competence in teaching is a gift not bestowed upon everyone and unlimited courses in professional Education will not make a teacher of one who lacks the innate attributes. Teaching is an art, admittedly one difficult to define. It demands a sympathetic understanding of students, their personalities and problems, the technique to draw forth their hidden talents and develop them. Every student has known teachers who have the ability, even charisma, to communicate, but no message; others demonstrate professional mastery, but lack the power to convey it.

In a provocative article, appearing in Political Science Quarterly, September 1952, a time when the "Cold War" monopolized the headlines, Peter Viereck bemoaned the totalitarian threat to three pillars upon which much of Western civilization rests - the parliament, the cathedral and the university. Having made the point, he did not elaborate upon it, but the implications would appear obvious - the parliament, where he seeks to master the very difficult art of governing himself; the cathedral, where he probes the meaning of the cosmos and the relationship between himself and the Infinite; the university, where he seeks knowledge in hope it may ultimately lead to wisdom, for the two are not the same.

Change appears to be a basic force operating throughout the cosmos. In terms of human society it has moved with bewildering tempo and revolutionary dynamism in the last generation. It is understandable and axiomatic that the university, in the service of changing society, must adapt to it. The question, rather, seems to be how far the university should depart from time-tested fundamentals of higher education. There is reason to believe that the university of today has lost, not its sense of mission, but of direction. Declining birth rates threaten an era of cut-throat competition to fill the classrooms and dormitories of higher educational institutions. While competition may be the lifeblood of a free economy, universities were not designed as profit-making enterprises subject to the patterns of the marketplace. The current dissatisfaction of the public with elementary and secondary schools may ultimately descend upon the universities if present debilitating trends continue. Are we in sight of the day when university graduates, like those of high 
schools, can neither read nor write? Students are being admitted who have neither talent nor capacity for higher education; standards are lowered to increase enrollment, which in turn becomes an argument for higher appropriations from state legislatures; grade inflation keeps incompetent students eligible for the next registration. Degree programs of inferior quality hold forth the promise of graduation for all comers. Demanding subjects-science, mathematics, foreign languages-are eliminated from requirements to insure degrees for all enrolled. What is happening to the dictum of Goethe that a man ignorant of a foreign language does not know his own? There are basic considerations intrinsic to the nature of the university. Highest priority should be the production of civilized human beings and recent years leave much to be desired. A university should inculcate values sustained over the centuries, not ephemeral vogues that fade with the season; whether the graduate be professional or nonprofessional, he does not merit the title of university man if he cannot distinguish between cut glass and diamond, brass and gold, sound and music, words and literature.

These are not bright days in the realm of historical studies. Lack of opportunity is turning students in other directions and most departments have suffered substantial losses in upper division enrollment. This is understandable and equally regrettable. Everyone was not meant to be a professional historian but history will always remain a sine qua non in the formation of an educated and cultured individual. Individually or collectively, we are only what our past has made us and there is no other key to understanding ourselves.

History is fascinating because it is human. Reduced to fundamentals it is the story of human experience and what could be more alluring? Too easily do we forget that human experience means joys and sorrows, exaltation and disappointment, pain and suffering, accomplishments and failures. For the student it is inspiring and moving to ascend the mountain top and watch the panorama of the centuries unfold-the first uncertain steps of primitive man toward civilization, the building of the Pyramids, the Exodus to the Promised Land, the erection of the medieval cathedrals, the rise and decline of nations, the sweep 
of numerous and diverse cultures, the spread of colony and empire, the lure of new worlds to explore, until we approach our own day with its highly complex institutions, the appalling threat of nuclear weapons, the landing of men on the moon and initial ventures in the conquest of space. History is a quest for pattern and meaning in the record of human experience. Gibbon, in a pessimistic moment, saw history as the register of the crimes and follies of mankind. Is it really nothing more than this? Is it, as early Christian philosophers maintained, the slow evolving of a Divine plan, too remote for our vision and too intricate for our understanding? Is it the result of a blind and meaningless accident that eons ago followed the chance fusion of some primordial particles of matter? Or does the answer lie at some point between these extremes? As I have often admonished graduate students, when grappling with such questions it is advisable to have a bottle of aspirin within easy reach.

In retrospect I view this odyssey in a spirit of satisfaction and contentment. It has been a rewarding pilgrimage bringing no major regrets and very few minor ones. In some respects it carried me farther than I ever anticipated traveling; in others it left me far short of earlier hopes and ambitions, but there must be few who do not ultimately pronounce such a verdict upon themselves. I look back fondly to school days in Muscatine, Davenport, and Iowa City, with gratitude to so many splendid people, teachers, friends, associates and colleagues, who over all my years gave so much and left their imprint upon me. There is a sense of pride in viewing today the university to which I have given forty-three years of service, its growth to maturity in academic atmosphere, its almost phenomenal expansion in plant and facilities, now numbering thirty buildings, half of them constructed since 1956, some twenty years after my arrival. Only later in life does one come to a fuller appreciation of the incomparable blessing of an education and the void that must exist in the lives of those deprived of it and those who had the opportunity and failed to rise to it. It is reassuring to believe that I had some small part in transmitting that heritage to others, some of them students who have excelled their master, much to my delight. These twilight years bring the hope and 
prayer that young men and women, who sat in my classes and seminars, will in their own good time express the same sentiments about me. If so, the seed will have fallen upon good ground, holding the promise of a bountiful harvest.

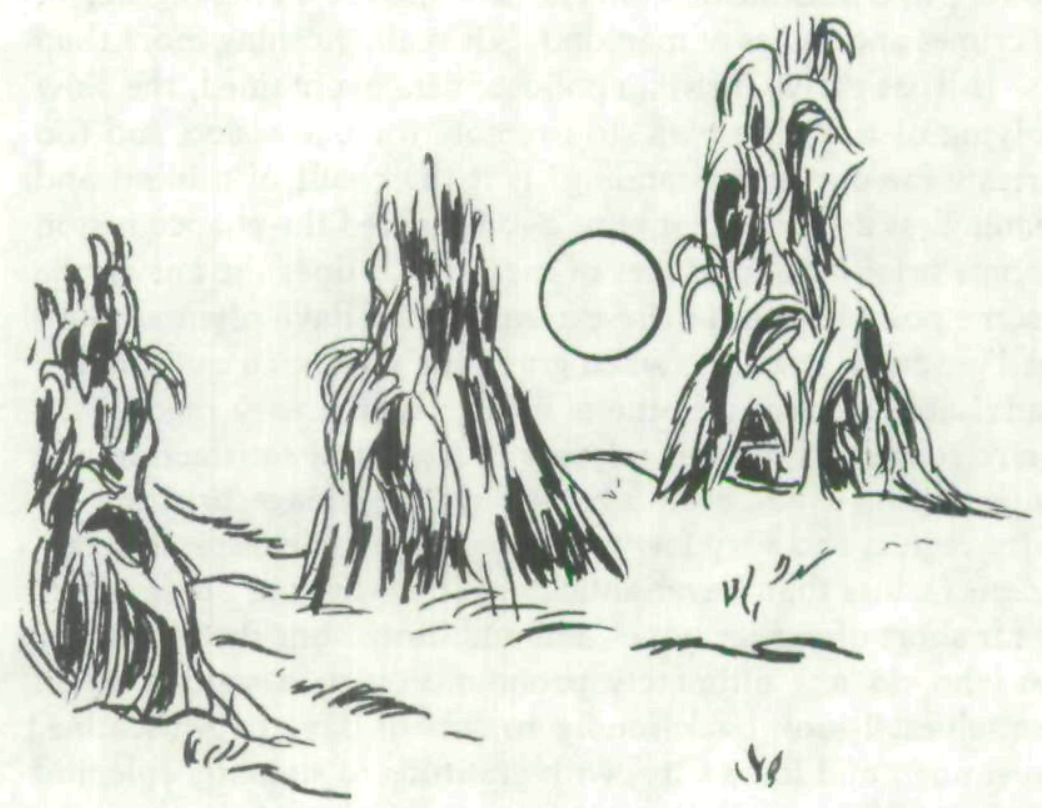

Note

${ }^{1}$ Orion Clemens, meeting with little success as publisher of the Hannibal Journal, in September, 1853, purchased an interest in the Muscatine Journal, assuming the post of editor. Moving with him from Hannibal were his mother and brother, Henry; his younger brother, Samuel (Mark Twain), joined the family in Muscatine in the summer of 1854, worked under Orion, probably as a compositor. Samuel remained until late in the fall or early in the winter of 1854-55. Orion left Muscatine June 9, 1855, to open a job printing business in Keokuk, where Samuel rejoined him for a period of slightly less than two years. There are two references to Muscatine in Life on the Mississippi in adjoining paragraphs, the first recounting a chance meeting with a demented individual who threatened physical violence, the second his tribute to the beauty of the summer sunsets. "I have never seen any, on either side of the ocean, that equaled them." 
Copyright of Annals of Iowa is the property of State of Iowa, by \& through the State Historical Society of Iowa and its content may not be copied or emailed to multiple sites or posted to a listserv without the copyright holder's express written permission. However, users may print, download, or email articles for individual use. 